\title{
Philosophy of Economics in Context of the Challenges of Modernity*
}

\author{
Andrey Orekhov \\ Department of Social Philosophy \\ Peoples' Friendship University of Russia (RUDN \\ University) \\ 6, Miklukho-Maklaya Street, Moscow, 117198, Russian \\ Federation \\ E-mail: orekhovandrey@yandex.ru
}

\author{
Fakhraddin Akhmedov \\ Department of Finance and Credit \\ Peoples' Friendship University of Russia (RUDN \\ University) \\ 6, Miklukho-Maklaya Street, Moscow, 117198, Russian \\ Federation \\ E-mail: akhmedov@mx.rudn.ru
}

\begin{abstract}
This article is devoted to the philosophy of economics as to the interdisciplinary area existing on a joint of philosophy and economy. Philosophy of economics «philosophical problems of economy» is the scientific interdisciplinary direction investigating the most fundamental, basic, and most metaphysical questions of development of an economy and economic science. Structurally, the philosophy of economics develops the following sections: methodological problems of philosophy of economy, market philosophy and philosophical problems of economic consciousness, economic axiology, economic ethics and anthropology. The problem of philosophy of economics in a context of the present challenges is to reflect successfully three threats: 1 . Dogmatism and traditionalism; 2. Relativism; 3. Anti-scientism and irrationalism). In addition, this article attempts to prove the right to existence as a scientific discipline, though this problem is very difficult (especially in conditions of methodological aggression from outside), from a social pseudo-science, containing groundless faultfinding and religionism.
\end{abstract}

Keywords—philosophy; economics; challenge; modernity

\section{INTRODUCTION: WHAT IS PHILOSOPHY OF ECONOMICS?}

The term philosophy of economics can be used in three major senses:

- Philosophy of economics, in our view is, first, a special direction in the history of the economic thought, investigating fundamental principles of an economic science taking into account their valuable components, including the subsequent orientation to economic policy. In this aspect, philosophy of economics unites economic axiology, economic anthropology and philosophy of economic policy. If we treat philosophy of economics in such aspect, then we interpret it, first, as the historical-economic doctrine, instead of a theoretical section of an

*This paper was financially supported by the Ministry of Education and Science of the Russian Federation on the program to improve the competitiveness of Peoples' Friendship University of Russia (RUDN University) among the world's leading research and education centers in the 2016-2020 economic science in general.

- In English economic literature, the philosophy of economics mainly means economic methodology (methodology of economics). The questions within the competence of the philosophy of economics in Russian tradition, in accordance of English literature, are distributed between other social sciences and directions. For example, the property philosophy and economic policy philosophy traditionally are within the competence of political philosophy, and the theme of ethics and economy is a subject of moral philosophy. Economic anthropology is studied in anthropology and etc.

- At last, in Russian tradition, the philosophy of economics is the same as the philosophical problems of economy (philosophical problems of an economic science), and this meaning of the term is structureforming, concerning the first two meanings (both of them can be presented as methodological deviations, deviations in relation to the third value).

Philosophy of economics (philosophical problems of economy) is scientific interdisciplinary direction investigating the most fundamental, basic, metaphysical questions of development of an economy and a science about an economy [1. P.9-10].

Three moments in this definition deserve specification.

- First, the philosophy of economics is within the scientific area of researches instead of pseudoscientific or, especially, not antiscientific. Philosophers of economy is guided by application of scientific methods of research concerning an economy for which there are characteristic severity, accuracy, substantiality, heuristic, consistency, a support on experience and experiment. The unscientific methods of research appealing to a myth, belief or authority, remain outside of actually philosophical-economic researches.

- Secondly, philosophy of economics is interdisciplinary in direction, existing as we already 
underlined simultaneously both a philosophical and an economic science. In other words, the philosophy of economics can be considered both a philosophy section and an economy section. The philosophy as philosophy of economics realizes the methodological function concerning an economic science: it formulates the most general, universal principles on which the economic science develops, forms outlook standards and ideals of development of an economic science, and sets an ethical orientation to development. The economic science, in turn, delivers the private economic facts and knowledge for philosophy, which form empirical base for the subsequent philosophical generalizations concerning an economy and a society in general.

- And, at last, thirdly, the philosophy of economics, in difference, for example, from the economic theory, is aimed at studying of not all economic problems but only the most basic, fundamental, and metaphysical, meaning that they are a core, quintessence of all economic knowledge. Definition of such problems, their allocation from all set of the economic facts and theories are also included into the competence of philosophy of economics.

The philosophy of economics is economic science has much commonality with other economic disciplines: the history of economic thought, the economic theory, etc. Nevertheless, most close to philosophy of economics in an economic science locate two disciplines - economic methodology (methodology of an economic science) and political economy.

\section{A. Philosophy of economics and economic methodology}

As it was already underlined, the philosophy of economics is closely connected with economic methodology as together with it is aimed at research of the most fundamental, basic problems of economic knowledge. Some problems of an economic science can be carried simultaneously both to philosophical problems and methodological problems. For example, it is a problem of the subject of an economic science, an economic law, etc., but, in general, between philosophy of economics and economic methodology, there are essential distinctions: if the economic methodology basically is concentrated to private research, the ways that conduct to designing of adequate ways of reception of new economic knowledge and their verification problems of philosophy of economics are slightly wider. The scale of global judgment regarding the role of an economy in a society and the prospects of development of an economic science that lead to reception of the knowledge is important not only for economy but also for others socially-humanities and spheres of a life of a society. For example, the problem of economic ideologies as a section of philosophy of economics is interesting to not only the economist but also the political scientist, the sociologist; and philosophical problems of economic anthropology should cause interest not only of the economist but also of the anthropologist and the philosopher. Thus, the philosophy of economics carries out integrating function concerning economic knowledge: it connects actually economic knowledge and knowledge of other sciences.

\section{B. Philosophy of economics and political economy}

The political economy can be treated as a special version of the economic theory with the problem of creation of system of rationally well-founded economic knowledge directed on political, sociological and philosophical levels. In this aspect, the political economy includes two floors of knowledge: the first floor is actually the economic knowledge. The second floor is knowledge of the sociological and philosophical. The political economy carries out some function of ideological discipline: the economic knowledge in that is developed as one of economic ideologies - Marxist, neoclassical, Keynesian, etc.

The philosophy of economics, unlike political economy, does not put before itself ideological problems and synthesizes knowledge of only two sciences - philosophies and economy. The philosophical analysis is not subordinated to interests of any ideology. The philosophy of economics is, first, a science, which itself reflexes values and ideologies. That is why any political economy requires the help from outside philosophy of economics, and the philosophy of economics completely but not necessarily deduces the results on level of political economic knowledge. The philosophy of economics can be one of the sources of the system of political economy and can exist, so more often and happens, out of any communication with political economy.

Structurally, the philosophy of economics develops of following sections:

- methodological problems of philosophy of economics (they are developed together with economic methodology); here concern the problem of a subject of an economic science and also a problem of principles, laws, categories and etc. can concern economic science. It is necessary to carry the methodological analysis to this section of philosophy of economics of own history (history of philosophy of economics);

- market philosophy ${ }^{1}$; it includes five basic directions: property philosophy, labour philosophy, philosophy of money, philosophy of the goods and a consumer choice.

- $\quad$ philosophical problems of economic consciousness; here the problem of economic ideologies, economic policy philosophy, and also economic philosophy philosophical reflexion concerning practical problems of an economy is often designated by the indistinct and uncertain term concerns;

- economic axiology; it includes the philosophicaleconomic analysis of a problem of justice, philosophy of economic freedom, and also in general

\footnotetext{
${ }^{1}$ The name is a little symbolic: it is obvious, for example that the property and labour existed before any market and before emergence of market economy
} 
research of a problem of values in an economic science and economic behavior;

- economic ethics and anthropology; here the philosophy of economics investigates problems of economic ethics, and also philosophical problems of economic anthropology.

TABLE I. STRUCTURE OF PHILOSOPHY OF ECONOMICS

\begin{tabular}{|l|l|}
\hline $\begin{array}{l}\text { Subject of an economic science } \\
\text { Principles and laws in an economic science } \\
\begin{array}{l}\text { The categorical analysis in an economic } \\
\text { science }\end{array}\end{array}$ & $\begin{array}{l}\text { Methodological problems } \\
\text { of philosophy of } \\
\text { economics (are developed } \\
\text { together with economic } \\
\text { methodology) }\end{array}$ \\
\hline $\begin{array}{l}\text { Property philosophy of economics } \\
\text { Labour philosophy }\end{array}$ & Market philosophy \\
$\begin{array}{l}\text { Philosophy of money } \\
\text { Philosophy of the goods and a consumer } \\
\text { choice }\end{array}$ & \\
\hline $\begin{array}{l}\text { Economic ideologies } \\
\text { Economic policy philosophy } \\
\text { «Economic philosophy» }\end{array}$ & $\begin{array}{l}\text { Philosophical problems of } \\
\text { economic consciousness }\end{array}$ \\
\hline $\begin{array}{l}\text { Philosophy of economic justice } \\
\text { Philosophy of economic freedom } \\
\text { Values in an economic science and } \\
\text { economic behavior }\end{array}$ & Economic axiology \\
\hline $\begin{array}{l}\text { Philosophical problems of economic } \\
\text { anthropology } \\
\text { Economic ethics }\end{array}$ & $\begin{array}{l}\text { Economic ethics and } \\
\text { anthropology }\end{array}$ \\
\hline
\end{tabular}

For example, the philosophy of money is the area directed on research of the essence of money, their places in the economy functioning, and most fundamental problems connected with existence of a monetary economy and its various phases. The philosophy of money cardinally differs from the theory of money.

The theory of money is the economic doctrine about money, about monetary circulation and as a financial sphere of economy. The doctrine shows how money in a society and in the financial sector of an economy functions. Arguments of the theory of money, as a rule, are expressed in economicmathematical language, supported with strict system of proofs, verified by the empirical facts and examples. We also notice that the theory of money considered money as eternal social and economic institute, invariable attribute of economy and a human society, since an epoch of decomposition of a primitive system.

The philosophy of money - is a philosophical-economic doctrine about the essence of money, about the metaphysical and ontological bases of a modern monetary economy, about money as to a philosophical-economic entity, and making deep impact on development of economy and all public life. As the philosophical-economic entity, money has a set of functions and purposes. They cannot be reduced completely to purely economic functions: money as a currency, money as accumulation means, etc. [2].

One more important section of philosophy of economics is the philosophy of economic freedom. Freedom - the major social value and rather significant social institute of a society. A free society is a democratic society: here human rights are observed, the policy is the tool of realization of will of the majority (though interests of minority also are considered).
The civil society serves as a counterbalance of bureaucratic expansion of the state, and the violence is applied only as an extreme measure.

There are some principal types of freedom: political, economic, intellectual, a freedom of worship, etc. For economic development, a key value is the concept of economic freedom.

Economic freedom is unlimited possibility for economic subjects to realize the economic interests, if it does not contradict the law.

Economic freedom is, along with private property and competition, the major element of a market economy. The subject here has the right to charge price freely, free to come to the market space and to leave it, and free to choose to itself both the buyer and the seller. The guarantor of economic freedom is private property. Any infringement of economic freedom is infringement of private property, and, on the contrary, infringement of a private property means an infringement of economic freedom.

Economic freedom in a society also has great influence over other types of freedom: political, intellectual, and religious (freedom of worship).

Political freedom allows economic subjects to transform most essential economic interests into interests political, and to defend them already at political organizations or the state structures (in particular, by means of lobbying).

Intellectual freedom gives the chance to economic subjects to pass an opinion freely about economic and political events and allows moving any knowledge and the information freely.

Information freedom plays a fundamental role in increase of efficiency of the market and in rough installations of the consumer, freedom of moving of people and capitals operates in aspect of achievement of a system effectiveness, and in aspect of more uniform distribution of riches between various territories [3. P.26].

The freedom of worship also has fundamental value for development of economic system. For a long time, it's been known (in particular, by M. Weber) that the pluralism of religions and possibility of free creed impulses development of capitalism and an industrial society in general; the same is probable, it is possible to tell and about a postindustrial society.

However, various types of freedom in certain cases can conflict with each other and then there's the issue of conflict of freedom. The conflict of freedom is a social situation when one freedom contradicts other freedom:

So, consumer freedom contradicts with necessity of protection of its health or well-being of other citizens, as in a case with the use of drugs, medicines, alcoholic drinks, tobacco, etc. [3. P.27]. 


\section{FUNCTIONS OF PHILOSOPHY OF ECONOMICS}

For what is the philosophy of economics necessary? Obviously, it should play a role of the discipline combining philosophy as a global science about general laws and principles all existing and economy as a private science about an economy. However, in our opinion, the integrating function is not unique in a set of all functions of philosophy of economics but is only one of its functions.

However, at first, let us define the functions of philosophy of economics.

Functions of philosophy of economics are those problems in which the philosophy of economics carries out in research of economic processes and as in what particularly it promotes development of an economic science.

In our opinion, there are six functions of philosophy of economy: world outlook, methodological, critical (skeptical), cultural genetic, forecasting and integrating.

\section{A. World outlook function}

World outlook function of philosophy of economics states that the philosophy of economics makes essential impact on outlook formation as professional economists and on outlook of all managing subjects. The philosophy of economics here puts the general basis of knowledge for complete vision of economic events and processes in future.

The outlook can be defined as set of sights, principles and the belief fixing the relation of the person to the natural and social validity. Besides outlook, it is possible to talk also about attitude, but the outlook is the higher form of a reflexion of the person concerning the world surrounding him.

Economic attitude is perception of the economic validity by means of sense organs, - so to say, external image.

Economic attitude is complete, total attitude; here the world of the economic phenomena appears in the fullest form.

Economic outlook is a complete, total attitude when the reason is connected to sense organs, rationality and the rational analysis.

Economic outlook is a set of sights, principles and the belief defining a place of each subject in system of relations with the economic world, - and through it, - in general with a society and the nature.

Concerning economic outlook, the philosophy, and, in particular, the philosophy of economics play a role of a theoretical kernel for formation of theoretical sights of the economists finding expression in economic theories created by them and models. It is natural that not all economists feel a theoretical kernel. Some, probably, will deny the influence of philosophy on formation of their outlook. However, such a kernel exists, and, from time to time, it is possible even to establish in the direct image connection between adherence of this or that economist of certain philosophy and interest to a concrete economic direction.

\section{B. Methodological function}

Methodological function of philosophy of economics consists that it plays a role of general methodology for an economic science, using the principles developed by philosophy in general. Further, these principles pass approbation in all methodology of social and the humanities, and then in economic methodology, - which, in turn, introduces them in an economic science.

Let's bring some examples of such principles. They may seem to some to be too elementary, too simple for the modern epoch, but it does not belittle their value.

\section{Development principle.}

This principle confirms generality of development, evolution for a considered reality - rather economically, economic reality. The idea of generality of development has started to take root in philosophy since works of ancient Greeks: Heracles, Protagoras, Gorgio, Socrates and Platoon. Subsequently, a principle of generality of development for a social reality have confirmed Hegel and Marx, contrary to a so-called metaphysical picture of the world where development was either absent in general or included only quantitative changes.

In an economic science, the metaphysics dominated for the long period: the economy should accept a certain ideal form (ideal trading balance, market balance, etc.). After that, only quantitative parameters, instead of qualitative, were subject to change. Only to Marxism, and subsequently Keynesian and institutionalism it was possible to bring a development principle to an economic reality. The newest directions of economy, such as evolutionary economy and new economic history, promoted entering of idea of development into an economic science.

Principle of determinism and principle of cognoscibility of the world.

These philosophical principles confirm the idea of general conditionality of all phenomena and the idea of their basic cognoscibility. Concerning economic phenomena, it is possible to tell the following: there are no incognizable economic processes and the phenomena, all of them are connected among themselves both economic process and the phenomenon has the reason.

Principles of a determinism and cognoscibility of the world were already practically generated in a classical science to the beginning of the 18th century. Economists took them from philosophy without special delays and problems, and Newton physics and mathematics was ready for them.

\section{Simplicity principle.}

Antique philosophers implicitly offered this principle, and its classical formulation was offered by the English philosopher of 14th century W. Occam so the principle has named Razor of Occam.

Razor of Occam: do not multiply entity over necessary. Otherwise: do not offer a difficult explanation there, where 
probably simple. Or: from all explanations at first choose most simple, and then search for more difficult.

This principle (sometimes is named as the principle economy of thinking) played and continues to play a huge role in development of economic knowledge. For example, he demands from economists not to take a great interest in construction of very bulky economic models, not to leave in speculative-idialogized schemes of consideration of an economic reality, and to be closer to a life.

Principle of practical powered by realizability.

Principle essence is the following: All is almost realizable, if it does not break laws of the nature and corresponds to technologies of modern science. Such kindergarten formulation should cause bewilderment: is this philosophical principle not familiar to economists?

Possibly, it is. However, economists obviously do not realize all huge value of this principle (and for some reason do not thank for it philosophy). For example, it is known, in medical and pharmacological science, millions and billions in search of vaccines against incurable illnesses (a HIVinfection, furiousness, etc.) are annually put. But who knows, what such vaccines in general can be created and can they exist in a reality? Nobody is certain, but, to the aid of private corporations and the state, investing in these projects, the principle of practical practicability comes: Creation of a vaccine against a HIV-infection (furiousness, etc.) is possible, as it does not contradict laws of the nature and corresponds to technologies of a modern science. But will somebody from serious investors give at least one dollar or ruble for creation of a perpetual mobile or for construction of the spaceship, capable to move with sub light speed? Nobody, for the first contradicts nature laws, and the second is not achievable from the point of view of technologies of a science of the beginning of 21 st century.

\section{Critical (skeptical) function}

Critical (skeptical) function of philosophy of economics represents an orientation of philosophical-economic knowledge on constant skepticism concerning the trues developed by an economic science. If the economic science in the majority of cases is inclined to consider these trues absolute, but philosophy of economics considers them mostly as relative trues, which can be changed in due course. If the economic science, as well as a mature science (by T.Kunu), to a certain extent is dogmatic, the philosophy of economics considers that all principles and economy laws should be exposed at any stage of its development to criticism and critical analysis provided that it is the rational criticism and rational analysis.

For example, discussing above the problems of philosophy of money, we specified that the economic science used to consider money eternal economic and social institute. But the philosophy of money does not consider like that and safely brings an attention to the question on the end of money. Whether there will be money or ever-social institute of money will stop the existence? Meanwhile, the answer to this question is known only to science fiction writers, but economists and philosophers only guess and assume:

\section{Cultural-genetic function}

Cultural-genetic function of philosophy of economics consists in formation by that the theoretical and methodological bases for designing of cultural values and samples for economic behavior.

In other words, the philosophy of economics takes part in formation and designing of samples and the norms of economic behavior exposing as standard-cultural wealth also ideals of the given concrete society, i.e. as economic culture. It is obvious also that these values and ideals should be high, i.e. comprise a spirituality element - as spiritual experience of humanity with strongly pronounced in it opposition of good and harm, high and low values, differently in itself cultural-genetic function of philosophy of economics can be misinterpreted.

\section{E. Forecasting function}

Forecasting function of philosophy of economics consists that last tries to predict, i.e. to extrapolate economic knowledge of the past and the present on the future events of an economic life. Thus, the philosophy of economics does not predict the future blindly and tries to make the forecast scientific and to develop philosophic-methodological base both for private and for global economic forecasts. In this aspect, forecasting function of philosophy of economics merges with its methodological function.

The forecast cannot be mixed with a prediction. The prediction is a guessing blindly; - even any person can be engaged in it. The prediction always assumes one outcome, but the forecast - some possible scenarios. Any forecast has always a forecasting horizon - time limit for the given forecast, but, at a prediction, it is absent.

However, it is necessary to notice that the economics' philosophy, in difference, for example, from economic prognostics (economic futurology) is not rigidly connected by these requirements. In philosophy of economics, some liberty of forecasting and forecasting on border with prediction is quite admissible. The philosophy of economics is really a problem of an economic science, but is also a philosophical problem, instead of any others. Flight of thought and imagination concerning the future in philosophy can be very high and is not connected to the rigid norms accepted in scientific forecasting.

\section{F. Integrative function}

Integrative function of philosophy of economics consists that it plays an intermediary role between economy and other socially-humanitarian and natural disciplines, stimulates an economic science to interdisciplinary interaction and interdisciplinary synthesis, and helps to comprehend the results received by an economic science as multidisciplinary, - i.e. as important not only for economists, but for scientists representatives of other disciplines. 
Interdisciplinary synthesis in an economic science can be carried out in three basic ways: economic imperialism, economic dependence and equal cooperation.

Economic imperialism is a method of research and type of interdisciplinary interaction in social sciences at which the major principle of an economic science is reproduced: effective achievement of the purposes at deficiency of means; the purposes can be thus various and are formulated by other social sciences: sociology, psychology, a political science, and etc.

Interdisciplinary interaction between economy and other social sciences like economic imperialism became more active since the 70 s and 80 s of the 20th century: also it is connected, possibly, with two principal causes: first, with a withdrawal of an economic science from rigid canons of neoclassic and the second coming of institutionalism as a direction much more open in a direction of the union with other social sciences; and, secondly, with aspiration of some social disciplines even more positive to formalize the conceptual device and methodological toolkit under natural sciences - mathematics, the physics, etc., and also partly under economy in model economics.

The strong influence of economic imperialism has undergone: gender researches, a demography, sociology, history, and a political science. In an overwhelming majority of cases, this influence should be considered as exclusively positive - as in respect of influence on evolution of the most economic knowledge, and in a foreshortening of development of that discipline which is exposed to influence from outside economy. For example, in the history such influence is connected with popularity of methodology of school new economic history, in a political science - with occurrence of the theory of a public choice, etc.

Economic dependence is a method of interdisciplinary interaction between economy and other science when economic research is conducted according to the methodological and theoretical bases of other science.

Economic dependence represents an underside of economic imperialism. If in case of the last as an aggressor in territory of another's science the economy acts, dictating it the methods in a case economic dependence other science imposes to an economic science the theoretical schemes and the methodology. Throughout all history, the economic science repeatedly was exposed to attacks from outside other social sciences, and, it is necessary to note, such attacks during the separate periods of development of economic thought were rather successful and had deep influence on development of the economic theory and methodology. For example, in German economic thought of the second half of the 19th century and the first of the 20th century, the economic discipline has visited a role of subordinate of a historical science, in Soviet social studies (1917-1991) an economic science was necessary to play a role of subordinate of Marxist-Lenin philosophy and its political colleague scientific communism, and etc.

It is possible to name the third way of interdisciplinary synthesis conditionally in the way of equal cooperation.
Equal cooperation is a type of interdisciplinary interaction when the economy and other social science equally influence working out of any research problems on joints among themselves, enriching and deepening both own, and another's theory and methodology.

Here it is necessary to consider as the most classical modern interaction between economy and sociology, and also between economy and psychology. Despite separate feeble efforts of economic imperialism and economic dependence, these pair of sciences on the first place have an interdisciplinary interaction known as equal cooperation. The economic sociology and economic psychology last years have achieved considerable successes, applying an effective combination in the first case - economic and sociological theory and methodology, and in the second - economic and psychological theory and methodology. Successful enough also it is necessary to recognize equal cooperation, economic and historical sciences, economic science and gender researches, and economic science and law.

\section{PHILOSOPHY OF ECONOMICS IN CONTEXT OF MODERNITY}

We have proved the existence of the philosophy of economics as a special philosophical and economic science. Now we should try to answer a question: how the philosophy of economics builds the relation to modern problems to the present in general?

This question has three basic foreshortenings.

The first foreshortening consists on ability of philosophy of economics to analyze the actual problems of the present: glocalisation, world community polarization to the third world and gold billion, an ecological and demographic problem, terrorism, etc. naturally that the philosophy of economics cannot and should not substitute all other social sciences in research of these painful points of modern society; its analysis is always purely philosophical-economic. The most important thing is that this analysis should be objective, weighed and capable to consider various points of view on a problem. Economic axiology and economic policy philosophy as components of philosophy of economics quite suit to formulate reasonable answers. That is why philosophers of economy should not be frightened and avoid global problems of the present and safely offer the versions of their decision. By the way, the philosophy of economics will realize the world outlook function.

The second foreshortening is interpretation by philosophy of economics as public modern problems, but all present. What is the today's present? What stage of development of a society we endure now, during what epoch we live, for example, during a postmodern epoch or during an epoch of a postindustrial society? What sphere of a society at present is the leader, what technologies prevail, what are formed requirements of people?

Our answer here is: philosophy of economics is not only economism but also posteconomism. Posteconomism is a new branch of modern post industrialism (theories of a postindustrial society). It's asserting that, during the 
postindustrial epoch economic, material relations will be overcome, removed by the principle of Hegel negationsynthesis. The postindustrial economic epoch de facto becomes not simply postindustrial, but post economic, where actually economic relations will already cease to play a defining role in behavior of people. The main ideologists of posteconomism are J.Masudu, M.Kastels, R.Inglhart, and Z.Bodrijjar. In general, posteconomism is closely connected with the concept of a postindustrial society and believes that it remains at present an overall objective of the overwhelming majority of the countries [4].

The third foreshortening is methodological. As the philosophy of economics is capable to answer present calls, i.e. on large methodological problems which are offered it by the present. In this aspect, it is possible to enter the concept of philosophical-economic challenge.

The philosophical-economic challenge is the research or methodological problem having paramount value for development of philosophy of economics and on which is forced to give any answers, to offer those or other decisions.

The challenge, which is not accepted, turns to threat; threat leads to crisis.

The difference of challenge from other problems facing to philosophy of economy consists that if the philosophy of economics will not be capable to answer on own philosophical-economic challenge. It is threatened with fundamental subject crisis owing to which it can in general cease to exist.

What in that case is possible to consider as a fundamental threat of philosophy of economics in present period of its existence?

In total, we would specify in three threats:

- dogmatism and traditionalism, resulting from the philosophy of economics;

- relativism in the form of universal skepticism and especially its postmodernist version;

- anti-scientism and irrationalism in the various versions, concerning a problem of a substantiation of philosophical-economic true; here as an example it is possible to result to the philosophy of economics and other types of an economic pseudo-science.

The problem of philosophy of economics in aspect of the present challenges is successfully to reflect all these three «challenges» and by that to prove the right to existence as scientific discipline.

\section{CONCLUSIONS}

It is possible to draw the following conclusions from our article:

1) philosophy of economics - philosophical problems of economy is a scientific interdisciplinary direction investigating the most fundamental, basic, and metaphysical questions of the development of an economy and a science about an economy.
2) Structurally, the philosophy of economics develops the following sections: methodological problems of philosophy of economics, market philosophy, philosophical problems of economic consciousness, economic axiology, economic ethics and anthropology.

3) Within modern scientific discourse, the philosophy of economics carries out the following functions: world outlook, methodological, critical, forecasting, cultural and integrative.

4) The problem of philosophy of economics in the context of calls of the present is successfully reflecting three threats (1. Dogmatism and traditionalism; 2. Relativism; 3. Anti-scientism and irrationalism) and by that to prove the right to existence as scientific discipline, - though this problem is very difficult, especially in conditions of methodological aggression from outside - from a social pseudo-science, groundless faultfinding and religionism.

\section{REFERENCES}

[1] Orekhov A.M. Philosophy of Economics in Russia: Birth of Tradition, Moscow: INFRA-M, 2012.

[2] Koratstsiari G. Ethics and Economics: the Question is Open//Voprosy Economiki, 1993, №8.

[3] Orekhov A.M., Akhmedov F.N. Economics and Contemporary Philosophy of Money: the Lessons of Crisis//Vestnik RUDN («Ekonomika»), Moscow: vol.2, P.5-12. 2013.

[4] Chistyakova O.V. Rationalization of Contemporary Culture and Education in the Context of Religious Resistance to Violence // Proceedings of the 2016 International Conference on Arts, Design, and Contemporary Education. Volume 64. (ICADCE 2016). Advances in Social Science, Education and Humanities Research. Atlantis Press. - Paris. France. 2016. P. 1192-1198 